WAINWRIGHT, L. K. (1956). J. gen. Microbiol. 14, 533-544

\title{
Spontaneous Mutation in Stored Spores of a Streptomyces sp.
}

\author{
BY LILLIAN K. WAINWRIGHT* \\ Department of Zoology, Columbia University, New York, U.S.A. and \\ Atomic Energy of Canada Ltd., Chalk River, Ontario, Canada
}

SUMMARY: Mutations were induced by storing non-dividing asexual spores of a Streptomyces sp. at $4^{\circ}$ for varying periods of time. Certain stages among spores germinated at $27^{\circ}$ were more 'sensitive' than others to this mutagenic action. This high sensitivity was not correlated with particular nuclear stages or with nuclear number. The increased frequency of mutants cannot be attributed to selection (either decreased survival of the wild type or selective growth of previously existing mutants), to increased background (gamma) radiation or to temperature shock. The data indicate that mutation rate is a function of the physiological condition of the spore and that mutations may occur in the absence of nuclear division.

The relative frequency of mutant colonies from stock suspensions of spores of a Streptomyces sp. strain T 12 stored in the cold increases with time. It seemed of interest to determine whether this increase was due to a simple selection phenomenon or whether some other factors were responsible.

Streptomyces T 12 was particularly suitable material for this study, because spore suspensions could be readily prepared which consisted almost entirely of uninucleate asexual spores, all in approximately the same physiological condition. These spores showed a high spontaneous frequency of morphological colony mutants $(0 \cdot 5-1 \cdot 0 \%)$, which were easily scored since they were clearly differentiated from the normal wild-type colony. Large volumes of spore suspensions could be stored for relatively long periods of time (i.e. 3 months) under standard conditions, making it possible to do large-scale experiments under controlled conditions. Under appropriate conditions the effect of storage in the cold could be demonstrated in a relatively short time (20-60 days in the early experiments, 8 days in later experiments).

As described below, the experimental results indicated that as a consequence of storage at $4^{\circ}$ new mutational events did, in fact, occur in the spores of Streptomyces T 12. These mutations were not a consequence of increases in background gamma radiation, nor was it likely that natural background radiation was inducing the changes. It seemed then that the material might provide some new evidence permitting a discrimination between the two hypotheses: $(a)$ that mutations arise as errors in the duplication of the genetic material (at the time of cell division); and (b) that mutations arise as a consequence of molecular changes caused by mutagenic chemicals within the cells (without the necessity of cell division).

* Present address: Department of Microbiology, Yale University, New Haven 11, Conn., U.S.A. 


\section{METHODS}

Asexual spores of strain $\mathbf{T} 12$ of Streptomyces sp. were used throughout these experiments. All platings were made on a peptone medium composed of: 'Bacto'-asparagine, 0.5 g.; 'Bacto'-peptone, 0.5 g.; $\mathrm{K}_{2} \mathrm{HPO}_{4}, 0 \cdot 05$ g.; glucose, 10 g.; 'Bacto'-agar, 15 g.; and distilled water, $1000 \mathrm{ml}$.

Fresh spore suspensions were prepared for each experiment. The growth from a single wild-type colony was suspended in water and the surfaces of five peptone agar plates were heavily inoculated with this suspension and incubated at $27^{\circ}$. After 10-14 days the confluent growth on these plates was flooded with cold water, scraped to loosen the spores, decanted, agitated in a 'Waring' Blendor in the cold for $1 \mathrm{~min}$. and filtered at $4^{\circ}$ through no. 2 Whatman filterpaper to remove any pieces of aerial mycelium (Newcombe, 1953 $a$ ). These suspensions were immediately stored at $4^{\circ}$. Nuclear counts made on stained preparations of these suspensions, using the method described by McGregor (1954), showed them to consist entirely of uninucleate spores and to be almost completely free from clumps of spores.

Spores were aged at $4^{\circ}$ in tubes of liquid medium (as above but without the agar) or on the surface of peptone agar on Petri plates. Except where indicated all manipulations of spores to be aged were performed in a cold room at $4^{\circ}$. To determine the frequency of mutants, samples were removed from the tubes, diluted when necessary in distilled water, spread on the surface of agar medium, and incubated at $27^{\circ}$ for 6 days. Plates with more than 100 colonies were never used for scoring mutant or viable counts. Where the spores were being aged on the surface of agar, the plates were simply removed from the cold room and incubated at $27^{\circ}$ for 6 days. The principal types of mutant colonies scored have been described elsewhere (Newcombe, 1953 $a$ ). In the experiments reported below the majority of mutant colonies were sectored. As the frequency of whole colony mutants paralleled that of sectored colony mutants, the results for the two classes are not reported separately. Sectored colonies were only scored as mutant when the sector obviously originated at the centre of the colony. This discrimination was not difficult since most sectors were obviously peripheral (arising late in the formation of the colony) or central sectors (arising at the time of origin of the colony).

Spores were irradiated with X-rays, using the same techniques as those described by Wainwright \& Nevill (1955). In our experiments, the exposure time was $4 \mathrm{~min}$. and the distance, $50 \mathrm{~cm}$.

\section{RESULTS}

\section{The effect of ageing spores on agar}

Preliminary experiments indicated that storage of a spore suspension of Streptomyces $\mathrm{T} 12$ in peptone medium at $4^{\circ}$ resulted in an increase in the absolute mutant count upon subsequent plating out. It was decided, therefore, to age the spores on solid medium to determine whether a similar increase in the mutant count could be observed in the absence of any possibility of differential 
growth with subsequent fragmentation of the germination tubes during the plating out. Under these conditions, with the spores fixed in position on the plates, an increase in the absolute number of mutant colonies would represent a real increase in the number of mutations and could not be due to selective overgrowth.

A series of 1000 plates was spread with a standard inoculum consisting of $\mathbf{0} \cdot \mathbf{1} \mathrm{ml}$. of spore suspension, and the plates were stored. At various intervals a number of the plates were incubated and subsequently scored for mutant and wild-type colonies; the results of one such experiment are presented in Table 1. At 35 days there was a significant increase in the average number of mutants/plate $(0 \cdot 24-0 \cdot 36)$. This increase was even more marked on the 37 th day. The results indicated that new mutational events occurred as a consequence of storage and suggested that any similar increases in the proportions of mutants from liquid medium were probably not due solely to selective overgrowth by the mutants.

Table 1. The frequency of mutants among spores of Streptomyces $T 12$ stored at $4^{\circ}$ on the surface of agar plates

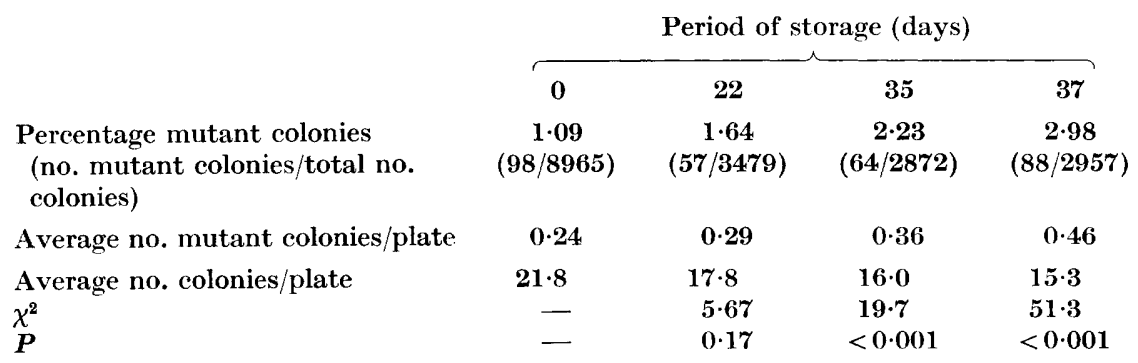

The $\chi^{2}$ values given are for comparisons with the 0 day determination of mutant frequency.

Five hundred and thirty-one mutant colonies were sampled and restreaked, and in every case the streaks showed a predominance of mutant colonies, most of which gave rise to further new variant types upon subculture (as described by Newcombe, $1953 a$ ). The changes studied were then true genetic changes in that they were heritable. Two hundred normal colonies were restreaked and in every case there was a predominance of wild type colonies. Although recombination has been observed in Streptomyces coelicolor (Sermonti \& Spada-Sermonti, 1955), it has not been observed in this strain $\mathrm{T} 12$. It has therefore not been possible to determine the nature of the mutational event.

The effect of an increased number of nuclei per spore during the period of storage upon the frequency of mutants obtained was tested in the following manner. Eight hundred plates were each spread with a standard inoculum of spores. Four hundred of the plates were immediately incubated at $27^{\circ}$ for $6 \mathrm{hr}$. (so that the average number of nuclei per spore would be $c .8$ ) and then returned to $4^{\circ}$ to be stored for 33 days along with 200 control plates which had been kept at $4^{\circ}$. The remaining 200 plates were incubated at $27^{\circ}$. The plates which had been preincubated at $27^{\circ}$ for $6 \mathrm{hr}$. before storage showed a marked 
increase in both the frequency and the average number of mutants/plate over both the control ( 0 day) plates and the plates which had been stored in the cold for the same number of days (Table 2).

Table 2. The frequency of mutants among spores of Streptomyces $T 12$ stored at $4^{\circ}$ on the surface of agar plates

\begin{tabular}{|c|c|c|c|}
\hline \multirow[b]{3}{*}{ Period of storage at $4^{\circ}$ (days) $\quad \ldots$} & \multicolumn{3}{|c|}{$\begin{array}{l}\text { Period of incubation at } 27^{\circ} \\
\text { before storage at } 4^{\circ}(\mathrm{hr} .)\end{array}$} \\
\hline & \multicolumn{2}{|c|}{0} & \multirow{2}{*}{$\begin{array}{c}6 \\
33\end{array}$} \\
\hline & $\mathbf{0}$ & 33 & \\
\hline $\begin{array}{l}\text { Percentage mutant colonies } \\
\text { (no. mutant colonies/total no. colonies) }\end{array}$ & $\begin{array}{c}0.91 \\
(156 / 17155)\end{array}$ & $\begin{array}{c}1 \cdot 87 \\
(85 / 4552)\end{array}$ & $\begin{array}{c}4 \cdot 08 \\
(157 / 3851)\end{array}$ \\
\hline Average no. mutant colonies/plate & $0 \cdot 39$ & $0 \cdot 42$ & $0 \cdot 78$ \\
\hline Average no. colonies/plate & $42 \cdot 6$ & $22 \cdot 6$ & $19 \cdot 2$ \\
\hline $\begin{array}{l}\chi^{2} \\
P\end{array}$ & - & $\begin{array}{l}29 \cdot 3 \\
<0 \cdot 001\end{array}$ & $\begin{array}{l}212 \cdot 4 \\
<0.001\end{array}$ \\
\hline
\end{tabular}

The $\chi^{2}$ values given are for comparisons with the 0 day determination of mutant frequency.

It should be noted that when long preincubation periods were used, the spores developed germination tubes before storage. Since both germinated and non-germinated spores behaved in the same fashion, for convenience the term preincubated"spores (or its equivalent) has been used irrespective of the length of the germination tube or the number of nuclei developed.

\section{The effect of varying the period and temperature of preincubation}

If the effect of preincubation noted above were a consequence of the increased number of nuclei, the extent of the effect might be expected to vary as the number of nuclei changed. A study was made, therefore, of the effect of varying the period of preincubation at $27^{\circ}$ from 0 to $24 \mathrm{hr}$. upon the mutant frequency of spores subsequently stored on plates at $4^{\circ}$ for a standard period of time. Ten ml. samples of a spore suspension diluted in peptone medium at $4^{\circ}$ were distributed into $16 \times 150 \mathrm{~mm}$. tubes. Half of the tubes were then incubated at $27^{\circ}$ by plunging them into a beaker of water at that temperature, agitating briefly and then permitting them to remain in the bath for periods up to $12 \mathrm{hr}$. For convenience to study the period from 12 to $24 \mathrm{hr}$. the remaining tubes were held at $4^{\circ}$ for $12 \mathrm{hr}$. and then incubated at $27^{\circ}$ for periods of $12-24 \mathrm{hr}$. When the tubes were removed from the $27^{\circ}$ bath, they were plunged into water at $4^{\circ}$, agitated briefly and plated immediately at $4^{\circ}$. Half of the plates at each time interval were immediately incubated at $27^{\circ}$, and the remainder were stored at $4^{\circ}$ for 8 days. The results of one such experiment are shown in Fig. 1. The frequency of mutants was not affected by the different preincubation periods ( 0 day storage) unless the spores were stored at $4^{\circ}$ for several days. After 8 days of storage the frequency of mutants rose to a maximum of $26 \%$ for $41 \mathrm{hr}$. of preincubation. As the period of preincubation was further increased, the mutant frequency decreased, indicating that sensitivity 
to storage was not a simple function of the number of nuclei. The second peak was not as reproducible as the first rise and fall. The maximum mutant frequency for spores preincubated at $27^{\circ}$ and stored for 8 days at $4^{\circ}$ generally occurred between 4 and $7 \mathrm{hr}$. of preincubation. However, this was not invariably the case, and the mutant frequencies observed in different experiments for the same conditions of preincubation and of storage are not necessarily entirely comparable (e.g. Fig. 1 and Table 5). Essentially similar results were

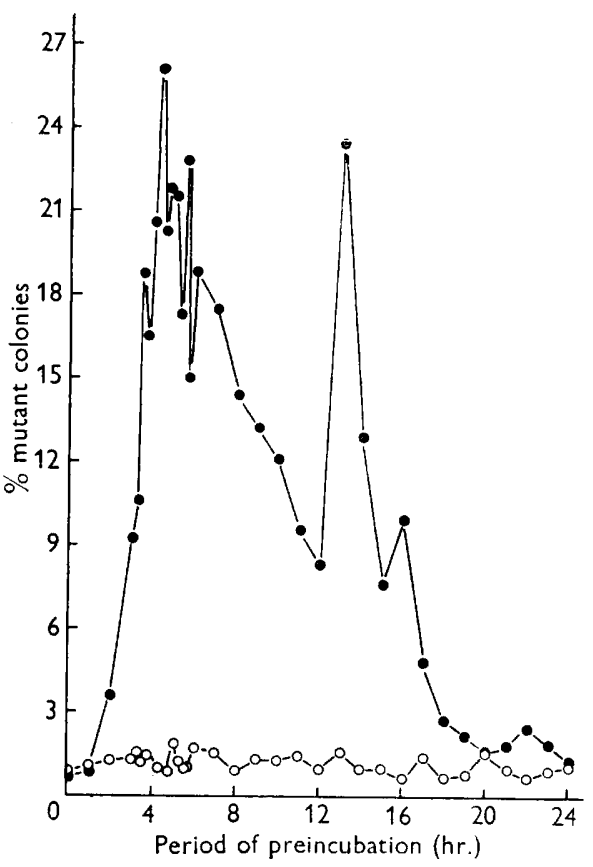

Fig. 1

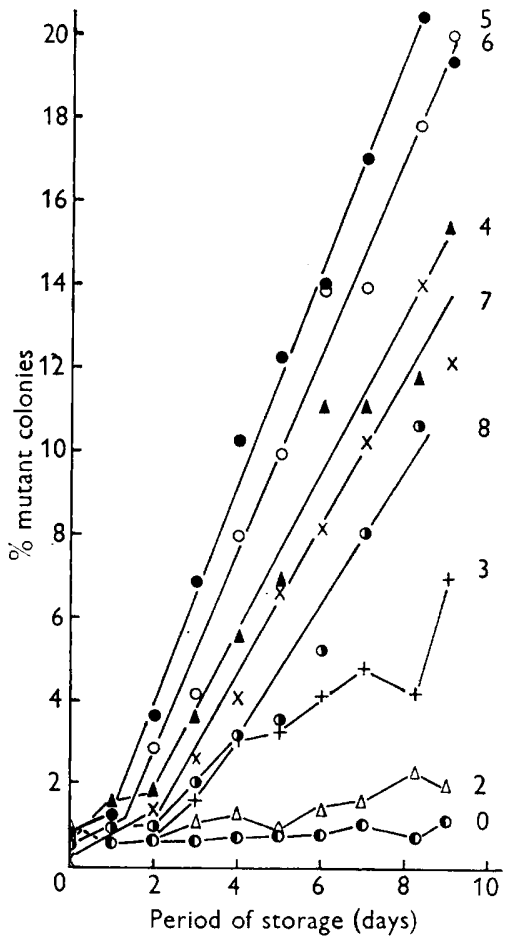

Fig. 2

Fig. 1. The percentage of mutant colonies arising from spores of Streptomyces sp. strain T 12 stored at $4^{\circ}$ for 0 days $(O)$ and 8 days $(O)$ as a function of the period of preincubation of the spores at $27^{\circ}$.

Fig. 2. The percentage of mutant colonies arising from spores of Streptomyces sp. strain T 12 preincubated at $27^{\circ}$ for $0 \mathrm{hr}$. (D), $2 \mathrm{hr}$. $(\triangle), 3 \mathrm{hr}$. $(+), 4 \mathrm{hr}$. $(\Delta), 5 \mathrm{hr}$. (O), $6 \mathrm{hr}$. (O), $7 \mathrm{hr} .(\times), 8 \mathrm{hr}$. (O); as a function of the length of time of storage at $4^{\circ}$.

obtained with spores which had been preincubated on plates, although the peak occurred approximately $2 \mathrm{hr}$. earlier. This shift was probably the result of a longer lag in the time for temperature equilibration of the agar plates after the changes.

If a specific nuclear or growth stage were more sensitive to cold storage than others, the temperature at which the spore was grown to reach that stage might be expected not to affect the response. On the other hand, if the physiological condition of the cell were important in determining the response 
of the cell to storage, the quantitative response to a given period of storage might be affected by a change in the temperature at which the spores were grown to reach the sensitive stage. A study was therefore made of the effect of varying the temperature of preincubation in peptone medium upon the mutant frequencies attained after subsequent storage under standard conditions. Table 3 presents results from such experiments. The spores preincubated at $27^{\circ}$ and $37^{\circ}$ showed similar values for the maximum mutant frequencies in different experiments, although the nuclear numbers at the time of these frequencies for the two temperatures were quite different. The peaks at $27^{\circ}$ ranged from 15 to $31 \%$ mutants, those for $37^{\circ}$ from 16 to $23 \%$. The maximum for spores preincubated at $27^{\circ}$ generally occurred at from 4 to $7 \mathrm{hr}$. (in one case $9 \mathrm{hr}$.) of incubation, while at $37^{\circ} 5 \mathrm{or} 6 \mathrm{hr}$. gave maximal values. Spores preincubated at $18^{\circ}$ reached peak mutant frequencies at $7-12 \%$, and these maxima (after 11 or $12 \mathrm{hr}$. preincubation) occurred when the number of nuclei were different from those for spores preincubated at $27^{\circ}$ and $37^{\circ}$. Thus sensitivity to storage did not correspond to a particular nuclear number or stage, but was rather a function of the physiological state of the spores. Cytological examination at 0 and 8 days for all these experimental suspensions indicated that no further growth of the spores had occurred during the storage at $4^{\circ}$ and no changes in the proportion of spores with different nuclear numbers were detected. The rates of increase of mutants on plates stored at $4^{\circ}$ after preincubation at $27^{\circ}$ for different periods of time are shown in Fig. 2. The rates appeared to differ with different preincubation periods.

Table 3. The effect of varying the temperature of preincubation of spores of Streptomyces $T 12$ on the mutant frequency achieved following standard conditions of storage

\begin{tabular}{|c|c|c|c|}
\hline \multirow[b]{2}{*}{$\begin{array}{c}\text { Temperature } \\
\text { of } \\
\text { preincubation } \\
\left({ }^{\circ}\right)\end{array}$} & \multirow[b]{2}{*}{$\begin{array}{l}\text { Highest } \\
\text { mutant } \\
\text { frequency } \\
(\%)\end{array}$} & \multicolumn{2}{|c|}{$\begin{array}{c}\text { Nuclear stage, proportion } \\
\text { of spores }\end{array}$} \\
\hline & & $\begin{array}{l}\text { With 4 nuclei } \\
(\%)\end{array}$ & $\begin{array}{l}\text { With more } \\
\text { than } 4 \text { nuclei } \\
(\%)\end{array}$ \\
\hline 18 & 12 & 23 & 7 \\
\hline 27 & 31 & 51 & 26 \\
\hline 37 & 23 & 0 & 100 \\
\hline
\end{tabular}

The effect of varying the post-storage incubation temperature

An attempt was made to discriminate between the following possibilities: (1) that new mutations occurred and became fixed in the absence of nuclear division; (2) that storage increased the likelihood of mutation (e.g. due to the accumulation of natural mutagen) in the early divisions during incubation at $27^{\circ}$ following storage in the cold. If the mutations occurred during storage, the number of mutants observed after a standard storage period might be expected to be largely independent of subsequent growth temperatures. On the other hand, if storage increased the likelihood of mutation in the early divisions after storage, the temperature of incubation after storage might be expected to affect the number of mutants observed. 
A study was made to determine whether variation in post-storage incubation temperature altered the mutant frequency. Spores were preincubated for 2 or $4 \mathrm{hr}$., spread on the surface of peptone agar plates and stored for a standard period. The plates were incubated at $18^{\circ}, 27^{\circ}$ and $37^{\circ}$. The results of three such experiments are shown in Table 4. The only significant deviations from the values for the control plates (incubation at $27^{\circ}$ ) were those for some spores incubated at $37^{\circ}$ (Table 4, columns $d$ and $f$ ). These results, were, however, inconsistent, in that the deviations were in opposite directions, and taken with the results of incubation at $37^{\circ}$ (column $b$ ) would seem to indicate that the changes in post-storage temperature had not affected the mutant frequency.

Table 4. The effect on mutant frequency of varying post-storage incubation temperature of spores of Streptomyces $T 12$ stored at $4^{\circ}$ on the surface of agar

\begin{tabular}{|c|c|c|c|c|c|c|c|}
\hline \multirow{3}{*}{$\begin{array}{l}\text { Post- } \\
\text { storage } \\
\text { incuba- } \\
\text { tion tem- } \\
\text { perature } \\
\quad\left({ }^{\circ}\right)\end{array}$} & & \multicolumn{6}{|c|}{ Period of storage at $4^{\circ}$ (days) } \\
\hline & & (a) & $(b)$ & (c) & $(d)$ & (e) & $(f)$ \\
\hline & & 0 & 16 & 0 & 14 & $0^{*}$ & $17^{*}$ \\
\hline 18 & $\begin{array}{l}\text { Percentage } \\
\text { mutants (no. } \\
\text { mutant colo- } \\
\text { nies/total no. } \\
\text { colonies) }\end{array}$ & $\begin{array}{c}1 \cdot 31 \\
(10 / 764)\end{array}$ & $\begin{array}{l}14 \cdot 3 \\
(19 / 133)\end{array}$ & $\begin{array}{c}1 \cdot 42 \\
(64 / 4494)\end{array}$ & $\begin{array}{c}24 \cdot 0 \\
(292 / 1215)\end{array}$ & $\begin{array}{c}1.57 \\
(25 / 1592)\end{array}$ & $\begin{array}{c}3 \cdot 52 \\
(32 / 908)\end{array}$ \\
\hline & $\chi^{2}$ & $0 \cdot 05$ & $0 \cdot 05$ & $2 \cdot 22$ & $0 \cdot 38$ & $0 \cdot 40$ & $3 \cdot 06$ \\
\hline & $P$ & $>0 \cdot 8$ & $>0 \cdot 8$ & $0 \cdot 14$ & $0 \cdot 56$ & $0 \cdot 5$ & $0 \cdot 08$ \\
\hline 27 & $\begin{array}{l}\text { Percentage } \\
\text { mutants (no. } \\
\text { mutant colo- } \\
\text { nies/total no. } \\
\text { colonies) }\end{array}$ & $\begin{array}{c}1 \cdot 32 \\
(10 / 760)\end{array}$ & $\begin{array}{c}11 \cdot 1 \\
(21 / 190)\end{array}$ & $\begin{array}{c}1 \cdot 05 \\
(47 / 4466)\end{array}$ & $\begin{array}{c}22 \cdot 9 \\
(314 / 1370)\end{array}$ & $\begin{array}{c}1 \cdot 25 \\
(21 / 1683)\end{array}$ & $\begin{array}{c}2 \cdot 12 \\
(21 / 999)\end{array}$ \\
\hline 37 & $\begin{array}{l}\text { Percentage } \\
\text { mutants (no. } \\
\text { mutant colo- } \\
\text { nies/total no. } \\
\text { colonies) }\end{array}$ & $\begin{array}{c}0.90 \\
(7 / 776)\end{array}$ & $\begin{array}{c}12 \cdot 0 \\
(16 / 133)\end{array}$ & $\begin{array}{c}1 \cdot 39 \\
(64 / 4593)\end{array}$ & $\begin{array}{c}18 \cdot 0 \\
(159 / 882)\end{array}$ & $\begin{array}{c}1 \cdot 86 \\
(29 / 1558)\end{array}$ & $\begin{array}{c}3 \cdot 70 \\
(36 / 973)\end{array}$ \\
\hline & $\chi^{2}$ & $0 \cdot 28$ & $0 \cdot 01$ & $1 \cdot 91$ & $7 \cdot 45$ & $1 \cdot 63$ & $3 \cdot 93$ \\
\hline & $P$ & $0 \cdot 62$ & $>0 \cdot 9$ & $0 \cdot 16$ & $0 \cdot 006$ & $0 \cdot 2$ & 0.05 \\
\hline
\end{tabular}

* These spore suspensions were preincubated at $27^{\circ}$ for $2 \mathrm{hr}$. prior to being plated and stored at $4^{\circ}$. The remaining spore suspensions were preincubated for $4 \mathrm{hr}$.

The $\chi^{2}$ values given are for comparisons with the corresponding control $\left(27^{\circ}\right)$ determinations of mutant frequency.

\section{The effect of intermittent chilling and warming on the frequency of mutants}

All aged spores were subjected to the same number of temperature changes. However, detailed experiments were done to determine whether the spores were more sensitive to temperature shock at some particular stages than at others. A standard spore suspension prepared at $4^{\circ}$ was divided into portions which were incubated at $27^{\circ}$ in liquid peptone medium for 0 and $2 \mathrm{hr}$. in one experiment and 0 and $4 \mathrm{hr}$. in another. Samples from these tubes were plated. Each tube was then chilled at $4^{\circ}$ for $15 \mathrm{~min}$., warmed to $27^{\circ}$ for $15 \mathrm{~min}$. and 
samples were again plated. This cycle of temperature changes was repeated. In addition, samples from a spore suspension were pre-incubated at $27^{\circ}$ in peptone medium for 0 and $5 \mathrm{hr}$., and then stored at $4^{\circ}$ for 8 days. Samples were then taken from these latter tubes and plated. The tubes were then subjected to one and two cold-warm cycles as described above. The results (Table 5) showed that no significant change in mutant frequency resulted from the repeated temperature shocks, whether applied before or after the storage period.

Table 5. The effect on mutant frequency of intermittent temperature changes before and after storage of spores of Streptomyces $T 12$

\begin{tabular}{|c|c|c|c|c|c|c|c|}
\hline 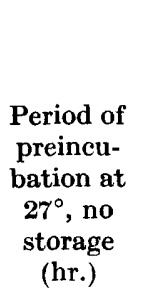 & $\begin{array}{l}\text { No. of } \\
\text { cold- } \\
\text { warm } \\
\text { cycles* }\end{array}$ & $\begin{array}{c}\text { Mutants } \\
(\%)\end{array}$ & $\begin{array}{c}\text { No. mutant } \\
\text { colonies/ } \\
\text { total no. } \\
\text { colonies }\end{array}$ & $\begin{array}{l}\text { Period of } \\
\text { preincu- } \\
\text { bation at } \\
27^{\circ} \text { fol- } \\
\text { lowed by } \\
\text { storage } \\
\text { at } 4^{\circ} \text { for } \\
8 \text { days } \\
\text { (hr.) }\end{array}$ & $\begin{array}{l}\text { No. of } \\
\text { cold- } \\
\text { warm } \\
\text { cycles }\end{array}$ & $\begin{array}{c}\text { Mutants } \\
(\%)\end{array}$ & $\begin{array}{c}\text { No. mutant } \\
\text { colonies/ } \\
\text { total no. } \\
\text { colonies }\end{array}$ \\
\hline o & o & $1 \cdot 83$ & $24 / 1309$ & 0 & 0 & $1 \cdot 20$ & $1 / 83$ \\
\hline 0 & 1 & $\mathbf{2 \cdot 3 0}$ & $30 / 1304$ & o & 1 & 1.53 & $13 / 849$ \\
\hline $\mathbf{0}$ & 2 & $2 \cdot 32$ & $30 / 1292$ & 0 & 2 & $1 \cdot 17$ & $8 / 864$ \\
\hline 2 & 0 & $1 \cdot 69$ & $22 / 1305$ & 5 & 0 & $3 \cdot 73$ & $51 / 1369$ \\
\hline 2 & 1 & $1 \cdot 76$ & $23 / 1309$ & 5 & 1 & $3 \cdot 83$ & $83 / 2166$ \\
\hline 2 & 2 & $1 \cdot 19$ & $15 / 1265$ & 5 & 2 & $3 \cdot 67$ & $64 / 1746$ \\
\hline 0 & 0 & $1 \cdot 16$ & $42 / 3619$ & & & & \\
\hline 0 & 1 & $1 \cdot 06$ & $40 / 3778$ & & & & \\
\hline 0 & 2 & $1 \cdot 19$ & $42 / 3530$ & & & & \\
\hline 4 & 0 & 0.92 & $41 / 4477$ & & & & \\
\hline 4 & 1 & 0.99 & $36 / 3631$ & & & & \\
\hline 4 & 2 & 0.84 & $18 / 2155$ & & & & \\
\hline
\end{tabular}

* Each cold-warm cycle consisted of a period of $15 \mathrm{~min}$. at $4^{\circ}$ followed by $15 \mathrm{~min}$ at $27^{\circ}$.

The effect of increasing the background radiation

To eliminate the possibility that the increased mutant frequency was due solely, or even in part, to the cumulative effect of any possible slight increases in the background radiation, samples of the same spore suspension were exposed to the gamma radiation emitted by a ${ }^{80} \mathrm{Co}$ source. Control spore suspensions shielded from the source were aged (at $4^{\circ}$ ) in parallel with suspensions which received doses corresponding to $\times 4 \cdot 4, \times 91$, and $\times 810$ the background count. After 11 and 21 days, samples were removed from the tubes and plated to determine the mutant frequency. In addition, after 21 days of storage, samples from both the control tubes and the tubes which had received $\times 810$ the background radiation dose were irradiated with $\mathrm{X}$-rays to determine whether a saturation level had been reached, or whether further mutations could be induced in those stored suspensions. The results (Table 6) indicated that increases in radiation dose far in excess of those encountered as background 
radiation did not cause any increase in the frequency of mutants among stored spores. Further, when spores, which had been irradiated at $\times 810$ background during storage, were irradiated with $\mathrm{X}$-rays, an increased mutant frequency was induced (21-day $\mathrm{X}$-radiated), indicating that the mutations arising during

Table 6. The effect on mutant frequency (\%) of increasing the background radiation during storage of spores of Streptomyces $T 12$ at $4^{\circ}$

The spore suspensions were incubated for $4 \mathrm{hr}$. at $27^{\circ}$ before storage at $4^{\circ}$. The radiation source used was ${ }^{60} \mathrm{Co}$.

$\overbrace{0} \frac{\text { Period of storage at } 4^{\circ} \text { (days) }}{21} \quad \begin{gathered}21 * \\ \text { (X-irradiated) }\end{gathered}$

\begin{tabular}{|c|c|c|c|c|}
\hline $\begin{array}{l}\text { No. times } \\
\text { background }\end{array}$ & Mut & $\begin{array}{l}\text { equency }(\% \\
\text { total coloni }\end{array}$ & $\begin{array}{l}\text { ratio mutan } \\
\text { parentheses) }\end{array}$ & ies : \\
\hline 1 & $\begin{array}{c}1 \cdot 10 \\
(50 / 4512)\end{array}$ & $\begin{array}{c}8 \cdot 49 \\
(228 / 2687)\end{array}$ & $\begin{array}{c}7 \cdot 68 \\
(63 / 820)\end{array}$ & $\begin{array}{c}16 \cdot 1 \\
(94 / 584)\end{array}$ \\
\hline $4 \cdot 4$ & $\begin{array}{c}1.02 \\
(43 / 4223)\end{array}$ & $\begin{array}{c}7 \cdot 24 \\
(212 / 2930)\end{array}$ & - & - \\
\hline $91 \cdot 4$ & $\begin{array}{c}1 \cdot 11 \\
(48 / 4338)\end{array}$ & $\begin{array}{c}7 \cdot 09 \\
(211 / 2975)\end{array}$ & - & 一 \\
\hline 810 & $\begin{array}{c}1.49 \\
(66 / 4435)\end{array}$ & $\begin{array}{c}6 \cdot 16 \\
(206 / 3346)\end{array}$ & $\begin{array}{c}7 \cdot 75 \\
(110 / 1419)\end{array}$ & $\begin{array}{c}12 \cdot 1 \\
(106 / 873)\end{array}$ \\
\hline
\end{tabular}

Table 7. Effect on mutant frequency (\%) of increasing the background radiation during storage of spores of Streptomyces $T 12$ at $4^{\circ}$

The radiation source used was ${ }^{\circ 0} \mathrm{Co}$.

\begin{tabular}{|c|c|c|c|c|}
\hline \multirow[b]{2}{*}{$\begin{array}{l}\text { Period of pre- } \\
\text { incubation } \\
\text { at } 27^{\circ} \\
(\mathrm{hr} .)\end{array}$} & \multirow{2}{*}{$\begin{array}{l}\text { No. of times } \\
\text { the background } \\
\text { radiation }\end{array}$} & \multicolumn{3}{|c|}{ Period of storage at $4^{\circ}$ (days) } \\
\hline & & \multicolumn{3}{|c|}{$\begin{array}{c}0 \\
\begin{array}{c}\text { Mutant frequency (\%) and ratio mutant colonies : } \\
\text { total colonies (in parentheses) }\end{array}\end{array}$} \\
\hline \multirow[t]{3}{*}{4} & 1 & $\begin{array}{c}1 \cdot 18 \\
(23 / 1945)\end{array}$ & $\begin{array}{c}9 \cdot 25 \\
(125 / 1352)\end{array}$ & $\begin{array}{c}12 \cdot 2 \\
(109 / 893)\end{array}$ \\
\hline & 810 & $\begin{array}{c}1.49 \\
(31 / 2078)\end{array}$ & $\begin{array}{c}6.45 \\
(96 / 1489)\end{array}$ & $\begin{array}{c}9 \cdot 45 \\
(103 / 1090)\end{array}$ \\
\hline & 1 & $\begin{array}{c}1 \cdot 36 \\
(29 / 2128)\end{array}$ & $\begin{array}{c}7 \cdot 00 \\
(90 / 1285)\end{array}$ & $\begin{array}{c}9 \cdot 13 \\
(48 / 526)\end{array}$ \\
\hline $5 \frac{1}{2}$ & 810 & $\begin{array}{c}1 \cdot 11 \\
(23 / 2066)\end{array}$ & $\begin{array}{c}5 \cdot 01 \\
(67 / 1338)\end{array}$ & $\begin{array}{c}7 \cdot 16 \\
(50 / 698)\end{array}$ \\
\hline
\end{tabular}

storage were not induced by low intensity radiation and that the cells were still capable of responding to high intensity radiation. The results of a similar experiment, in which samples were plated after 0,3 and 6 days, are shown in Table 7. These results also show that increased background radiation was not responsible for the increased mutant frequency. 


\section{The effects of various other treatments}

Spore suspensions, which had been preincubated for 4 or $5 \mathrm{hr}$. (to bring them to a more sensitive condition), were stored in distilled water at a concentration of $c .500$ spores $/ \mathrm{ml}$. for a standard period of time. Significant increases in mutant frequency were observed in these suspensions. Limited tests showed that storage of spore suspensions at $-14^{\circ}$ after freezing still produced significant increases in mutant frequencies. The frequency of mutants following storage was the same whether the spores were stored in continuous light (ordinary incandescent electric bulb) or continuous darkness. The presence of added calcium salts, or of versene during storage was without effect upon the mutant frequency.

\section{DISCUSSION}

There have been numerous reports that storage of seeds and pollen (Navashin, 1933; Cartledge, Murray \& Blakeslee, 1935; Stubbe, 1936; Nichols, 1941), sperm (Kaufman, 1947; Muller, 1946) and bacteria (Kaplan, 1947; Ryan, 1955) has resulted in increases in the frequency of mutations or chromosomal aberrations. However, in general, the results, though suggestive, are equivocal. In some materials (e.g. male Drosophila) there is the possibility that additional divisions of genetic material occurred, while in others it has not been possible to eliminate rigorously the alternative of greater survival of spontaneous mutants which were present before storage than of the non-mutants. The observations of Ryan (1955) established that new mutations can occur in non-dividing populations of Escherichia coli, maintained in medium exhausted of a limiting growth factor. The present experiments clearly demonstrate that new 'spontaneous' mutational events occurred as a consequence of storage of spores of a Streptomyces sp. under conditions where there was no nuclear division, although they do not indicate the nature of the mutational events.

This increased mutation frequency might be a consequence of either mutations which occurred during the storage and without visible nuclear division, or to an increased probability that mutations will occur in the early divisions following storage. It has not been possible to discriminate critically between these two possibilities. However, the results of the experiments in which the post-storage temperature was varied strongly suggest that the former possibility is more likely. The temperature coefficient of the mutation process in Drosophila has been observed to be of the order of $3 \cdot 6-6.5$ for a $10^{\circ}$ rise in temperature. It seems probable that the mutational event is a chemical reaction, and thus the observed value of unity for the $Q_{10}$ of the processes occurring subsequent to storage, implies that the mutations did, in fact, occur during the storage in the cold. In either event our results are compatible with the hypothesis that mutations occur as errors in the copying of the genetic material. Although no nuclear division was detected in these experiments, the cells may have been metabolizing at a slow rate and duplicated the genetic material without cell division. If this were the case, the number of errors made in this duplication might then be a function of the length of time of storage. On 
the other hand, an increased probability of occurrence of an error in gene duplication in the early divisions following storage might be attributed to the accumulation of some mutagens (Newcombe, 1953 b). The hypothetical mutagen might be a normal metabolic product (Novick \& Szilard, 1952), and the amount accumulated would be expected to be dependent upon the length of the period of storage. However, it may be noted that the $Q_{10}$ value of unity obtained for the mutational processes occurring subsequent to storage would require that for stored spores the overall process of gene replication (as distinct from nuclear division) be temperature independent, at least during the first replications after storage.

Influences of the physiological state of the cell on spontaneous mutation have been reported for Drosophila (Muller, 1946; Lamy, 1947). Although the time of occurrence of the mutation cannot be critically determined from our experiments, it is of interest to note that the peak of the mutation frequency curve does not appear to correspond to a particular nuclear stage, suggesting that the overall metabolic condition of the spores is of importance in determining the mutagenic effect of storage. If the mutations were occurring during storage, it is clear that they were not associated with a particular nuclear stage but with the physiological condition of the cell. If the mutations were occurring after storage, the mutation rate of spores grown under standard conditions differed according to the growth conditions prior to and during storage and were temperature independent.

I wish to express my thanks especially to Prof. F. J. Ryan for his valuable advice and much encouragement at all stages of this investigation; to Dr H. B. Newcombe for calling my attention to the phenomenon, for his advice and for generously providing facilities; and to J. F. McGregor and A. Nevill for their valuable assistance in different phases of the work. The work described in this paper was performed while the author had a Predoctoral Fellowship from the National Science Foundation, and was submitted in partial fulfilment of the requirements for the degree of Doctor of Philosophy in the Faculty of Pure Science of Columbia University.

\section{REFERENCES}

Cartledge, J. L., Murray, N. J. \& Blakeslee, A. F. (1935). Increased mutation rate from aged Datura pollen. Genetics, 21, 597.

KAPLAN, R. W. (1947). Spontane Mutabilität bei Bacterium prodigiosum. Z. Naturf. $2 b, 308$.

Kaufman, B. P. (1947). The spontaneous mutation rate in Drosophila. Amer. Nat. 81,77 .

LAMY, R. (1947). Observed spontaneous mutation rates in relation to experimental technique. J. Genet. 48, 223.

McGregor, J. F. (1954). Nuclear division and the life cycle in a Streptomyces sp. J. gen. Microbiol. 11, 52.

Muller, H. J. (1946). Physiological effects on 'spontaneous' mutation rate in Drosophila. Genetics, 31, 225.

Navashin, M. (1933). Origin of spontaneous mutations. Nature, Lond. 131, 436.

Newcombe, H. B. (1953a). Radiation-induced instabilities in Streptomyces. J. gen . Microbiol. 9, 30.

Newcombe, H. B. $(1953 b)$. The delayed appearance of radiation-induced genetic change in bacteria. Genetics, 38, 134. 
Nrchols, C. (1941). Spontaneous chromosome aberrations in Allium. Genetics, 26, 89.

Novick, A. \& Szilard, L. (1952). Anti-mutagens. Nature, Lond. 170, 926.

RYAN, F. J. (1955). Spontaneous mutation in non-dividing bacteria. Genetics 40, 726.

Sermonti, G. \& Spada-Sermontr, I. (1955). Genetic recombination in Streptomyces. Nature, Lond. 176, 121.

Stubbe, H. (1936). Die Erhöhung der Genmutationsrate in alternden Gonen von Antirrhinum majus L. Biol. Zbl. 56, 562.

Wainwright, S. D. \& Nevill, A. (1955). Some effects of post-irradiation treatment with metabolic inhibitors and nutrients upon X-irradiated spores of Streptomyces. J. Bact. 70, 547.

(Received 11 October 1955) 